cannot be taken by itself as a justification for such trials. Each trial must be justified on its merits, which involve far broader issues than can be discussed here. Indeed, in the light of more than 35 studies confirming the benefits of maintenance treatment for schizophrenia the original trial would be unjustifiable if proposed today. Trials of new drugs for patients who have already relapsed would be judged on a different basis.

The follow up study was conducted at the academic unit for clinical psychopharmacology at Guy's Hospital Medical School, London. We are grateful to Dr R Gaind and Dr D Bennett; the community psychiatric nurses and medical records staff of St Olave's and St Francis hospitals; Dr A A Schiff of E R Squibb and Sons; and Mrs Carol Neale and Mrs Phyl Maskell, who typed all the drafts of the manuscript.

\section{References \\ 1 Hirsch SR, Gaind R, Rohde PD, Stevens BC, W'ing JK. Outpatient maintenance of chronic schizophrenic patients with long-acting fluphenazine: double-blind placebo trial. $\mathrm{Br}$.Med $\mathcal{J}$ $1973 ;$ i $633-7$. \\ 2 Wing JK. Cooper JE, Sartorius $\mathrm{N}$. The measurement and classification of psychiatric symptoms. Cambridge: Cambridge University Press, 1974. \\ 3 Mindham RH, Gaind R, Anstee BH. Comparison of orphenadrine and placebo on the control of phenothiazine-induced parkinsonism. Psychol.Med 1972;2:406-13 \\ 4 Knights A, Okasha MS. Salih MA, Hirsch SR. A trial of fluphenazine versus flupenthixol in maintenance of schizophrenic outpatients. Br f Psychiatry 1979;135:515-23.}

5 Platt S, Weyman A, Hirsch SR, Hewett S. The social behaviour assessment schedule (SBAS): rationale, contents, scoring and reliability of a new interview schedule. Soc Psychiatn 1980;15:43-55.

6 Platt S, Hirsch S, Wevman A. Social behaviour assessment schedule (SBAS). 3rd ed. Windsor: NFER-Nelson, 1983

7 Stevens BC. Role of fluphenazine decanoate in lessening the burden of chronic schizophrenics in the community. Psychol Med 1973;3:141-58.

8 Brockington IF, Kendell RE, Leff JP. Definitions of schizophrenia: concordance and prediction of outcome. Psychol Med 1978;8:387-98.

9 Curson DA, Barnes TRE, Bamber RW, Platt SD, Hirsch SR, Duffy JC. Long-term depot maintenance of chronic schizophrenic outpatients: the seven year follow-up of the Medical maintenance of chronic schizophrenic outpatients: the seven year follow-up of the Medical
Research Council fluphenazine placebo trial. I. Course of illness, stability of diagnosis, and the Research Council fluphenazine placebo trial. I. Course of illness, stabily
role of a special maintenance clinic. Br f Psychiatry 1985;146:464-9.

10 Curson DA, Barnes TRE, Bamber RW', Platt SD, Hirsch SR, Duffy JC. Long-term depot maintenance of chronic schizophrenic outpatients: the seven year follow-up of the Medical Research Council fluphenazine placebo trial. II. The incidence of compliance problems, sideeffects, neurotic symptoms and depression. Brf Psychiatry 1985; 146:474-80.

11 Curson DA, Barnes TRE, Bamber RW, Platt SD, HIrsch SR, Duffy JC. Long-term depot maintenance of chronic schizophrenic outpatients: the seven year follow-up of the Medical Research Council fluphenazine/placebo trial. III. Relapse postponement or relapse prevention? The implications for long-term outcome. Br $\mathcal{F}$ Psychiatr 1985;146:474-80.

12 Barnes TRE, Milavich G, Curson DA, Platt SD. Use of the social behaviour assessment schedule SBAS in a trial of maintenance antipsychotic therapy in schizophrenic outpatients: pimozide versus fluphenazine. Soc Psychiatn. 1983;18:193-9.

13 Davis JM. Overview: maintenance therapy in psychiatry. I. Schizophrenia. Am $\mathcal{F}$ Psychiatry 1975;132:1237-45.

14 Johnson DAW. Haloperidol decanoate and the treatment of chronic schizophrenia. In: Johnson DAW, ed. Therapeutics today. Vol 2. New York: Adis Press, 1982

15 Freiman JA, Chalmers TC, Smith H, Kuebler RR. The importance of beta and the type II error and sample size in the design and interpretation of the randomized control trial. $N$ Engl f Med 1978;299:690-4.

16 Fleiss JL. Statistical methods for rates and proportions. New York: Wiley, 1973:1976-94.

Accepted 28 fuly 1986

\title{
Plasminogen activators in human colorectal neoplasia
}

\author{
J S K GELISTER, M MAHMOUD, M R LEWIN, P J GAFFNEY, P B BOULOS
}

\begin{abstract}
A crucial step in the transition from adenomatous polyp to invasive colorectal cancer is the degradation of the epithelial basement membrane. Plasminogen activators may play a part in regulating the extracellular protease environment necessary for this to occur. Both functional and antigenic activity of the two principal activators of plasminogen, tissue plasminogen activator and urokinase, were measured in $\mathbf{3 0}$ colorectal cancers, matched samples of mucosa, and eight adenomatous polyps. Both polyps $(\mathbf{p}<\mathbf{0 . 0 1})$ and carcinomas $(\mathbf{p}<0.001)$ had raised urokinase activities compared with normal mucosa, the activity being highest in the carcinomas. Activity of tissue plasminogen activator, however, was diminished in both polyps $(\mathbf{p}<0.01)$ and carcinomas $(\mathbf{p}<0.001)$ compared with normal mucosa, the values being lowest in carcinomas. Plasmin generation by urokinase-in contrast with tissue plasminogen activator-is fibrin independent and thus less subject to physiological control.
\end{abstract}

Department of Surgery, University College London, The Rayne Institute, London WC1E 6JJ

J S K GELISTER, FRCS, surgical research fellow

M R LEWIN, PHD, senior research fellow

P B BOULOS, MS, FRCS, senior lecturer in surgery

National Institute of Biological Standards and Control, London NW3 6RB M MAHMOUD, MSC, senior scientific officer

P J GAFFNEY, DSC, FRCPATH, senior scientist

Correspondence to: $\mathrm{Mr}$ Gelister.
This capacity to produce urokinase may be an important factor contributing to the malignant potential of adenomatous polyps and to the invasive quality of established carcinomas.

\section{Introduction}

The generation of proteolytic enzymes, including those of the fibrinolytic system, has been implicated in the development and spread of cancer. Fibrinolytic activity results from the conversion of the proenzyme plasminogen to the active proteolytic enzyme plasmin, induced by plasminogen activators. Such activators exist in two well characterised forms-tissue plasminogen activator and urokinase-which may be distinguished immunologically and by differences in molecular weight. The principal physiological role of tissue plasminogen activator is to maintain the vascular tree free of fibrin; but a corresponding role for urokinase is less clear.

In malignant tissue plasminogen activators have been ascribed various functions by the activation of plasminogen. These include destruction of tumour associated fibrin ${ }^{1}$ and the basement membrane glycoprotein components fibronectin and laminin, as well as activation of latent collagenase. ${ }^{2}$ Aberrations in production of plasminogen activator, both qualitative and quantitative, have been associated with experimental ${ }^{3}$ and human cancer. ${ }^{4}$ Most studies of fibrinolysis in human cancer have focused on overall tissue plasminogen activator activity. ${ }^{56}$ The results, however, have been contradictory and it was not possible to distinguish urokinase from tissue plasminogen activator, as these activators have been characterised only comparatively recently. By employing indirect immunological methods, however, it has been reported that urokinase is produced by malignant colorectal tissue but not by normal mucosa, ${ }^{7}$ and this finding was supported by an immunoperoxidase study which localised urokinase in colorectal tumours but not in normal 
mucosa. ${ }^{8}$ Urokinase has therefore been suggested as a tumour marker. ${ }^{9}$ To date there have been no specific quantitative studies of tissue plasminogen activator and urokinase in either normal or malignant colorectal tissue. We decided to analyse and quantify by specific and sensitive techniques, both immunological and functional, the activities of urokinase and tissue plasminogen activator in malignant, premalignant, and normal colorectal mucosa.

\section{Patients and methods}

Tissue was obtained fresh from 30 patients after a resection for colorectal cancer. Samples were removed by an independent pathologist from the centre and edge of the tumour and from macroscopically normal mucosa surrounding the tumour and at the edge of the resection. Samples were also obtained from eight patients having adenomatous colorectal polyps removed. An independent histological diagnosis was made in all patients. All tissue was washed in phosphate buffered saline, frozen in liquid nitrogen,

\section{Results}

The table summarises the results.

Fibrin plates-No lysis was seen on plasminogen free plates that served as negative controls. There was significantly less activity in carcinoma homogenates than in normal mucosa $(p<0.001)$ but there was no difference between either the centre and edge of the tumours or between distant and surrounding mucosa. Adenomatous polyps had activity intermediate between that of malignant tissue and normal mucosa but did not differ significantly from either

Tissue plasminogen activator-Normal mucosa had consistently raised activities of tissue plasminogen activator compared with both carcinomas $(\mathbf{p}<0.001)$ and adenomatous polyps $(\mathbf{p}<0.01)$, as measured by both bioimmunoassay and enzyme linked immunosorbent assay (table). There was no difference between tissue from the tumour edge or centre. Mucosa adjacent to the tumour, however, showed less tissue plasminogen activator activity than distant mucosa $(\mathbf{p}<0.01)$ by both assays. Though polyps showed tissue plasminogen activator activities just higher than carcinomas on enzyme linked immunosorbent assay $(p<0.05)$, activities found by bioimmunoassay were in the cancer range.

Median (range) plasminogen activator activity in colorectal neoplasia

\begin{tabular}{|c|c|c|c|c|c|}
\hline \multicolumn{3}{|c|}{ Assay } & \multirow{2}{*}{$\begin{array}{l}\text { Distant mucosa } \\
395(255-644)\end{array}$} & \multirow{2}{*}{$\frac{\text { Polyps }}{294(223-352)}$} & \multirow{2}{*}{$\begin{array}{l}\text { Tumour centre } \\
263(58-544)\end{array}$} \\
\hline Fibrin plate lysis are & $a(m m)$ & & & & \\
\hline Tissue plasminogen & activator $(\mathrm{IU} / \mathrm{ml})\}$ & $\begin{array}{l}\text { Bioimmunoassay } \\
\text { Enzyme linked immunosorbent assay }\end{array}$ & $\begin{array}{l}4 \cdot 1(1 \cdot 5-16 \cdot 0) \\
2 \cdot 1(1 \cdot 1-6 \cdot 0)\end{array}$ & $\begin{array}{l}1 \cdot 3(0 \cdot 8-3 \cdot 9) \\
1 \cdot 2(0 \cdot 5-5 \cdot 0)\end{array}$ & $\begin{array}{l}0 \cdot 8(0 \cdot 2-3 \cdot 5) \\
0 \cdot 7(0 \cdot 3-1 \cdot 5)\end{array}$ \\
\hline Urokinase $(\mathrm{IU} / \mathrm{ml})$ & $\left\{\begin{array}{l}\text { Bioimmunoassay } \\
\text { Enzyme linked in }\end{array}\right.$ & munosorbent assay & $\begin{array}{l}0 \cdot 2(0 \cdot 2-0 \cdot 9) \\
0 \cdot 7(0 \cdot 3-4 \cdot 3)\end{array}$ & $\begin{array}{l}0.4(0 \cdot 2-1 \cdot 0) \\
1 \cdot 3(0 \cdot 9-1 \cdot 8)\end{array}$ & $\begin{array}{l}0 \cdot 7(0 \cdot 2-4 \cdot 2) \\
2 \cdot 7(0 \cdot 4-9 \cdot 6)\end{array}$ \\
\hline
\end{tabular}

and stored at $-70^{\circ} \mathrm{C}$. Weighed portions from each sample were disintegrated by a cryofragmentation technique ${ }^{10}$ utilising a Mikro Dismembrator II (B Braun) with suspension of the resultant powder in a fixed weight to volume ratio of phosphate buffered saline containing azide $(1 \mathrm{~g} / 40 \mathrm{ml})$. Activity of the homogenates was assessed by the following methods.

Fibrin plates were made by a standardised technique ${ }^{11}$ using Kabi L grade fibrinogen at $1 \mathrm{~g} / 1$ in imidazole buffered saline, $\mathrm{pH} \mathrm{7 \cdot 4}$. A sample of fibrinogen was purified on a lysine-Sepharose column (Pharmacia) to remove plasminogen and used as a negative control. Thirty microlitres of sample was assayed in triplicate on each of two plates and the results expressed as lysis areas after incubation for 21 hours at $37^{\circ} \mathrm{C}$. The assay was performed on all samples from the centre of the tumours, polyps, and distant mucosa and on 15 samples from the edge of the tumours and surrounding mucosa.

Bioimunoassay, employed to measure specific functional activity of tissue plasminogen activator and urokinase in the homogenate supernatants, has been described in detail ${ }^{12}$ and was performed for both activators in 30 samples from the centre of the tumours and distant mucosa, in 15 samples from the edge of the tumours and surrounding mucosa, and for tissue plasminogen activator in eight and urokinase in six polyps. The procedure entails coating multiwell plates with the IgG fraction from a rabbit antiserum to purified human melanoma tissue plasminogen activator or purified human urokinase. Plasminogen and the chromogenic substrate S2251 (KabiVitrum) were added to each well and the resultant colour change read in a Titertek automatic multiscan reader as optical density at $405 \mathrm{~nm}$. Results (expressed in IU/ml homogenate) were determined from a standard dilution curve of the World Health Organisation standard for urokinase or tissue plasminogen activator.

Immunoassay of plasminogen activators-A two site enzyme linked immunosorbent assay using goat and rabbit antibodies to tissue plasminogen activator and urokinase respectively was employed. The assay was performed for both activators in 16 matched samples of tumour centre, edge, and distant mucosa; for eight polyps; and for tissue plasminogen activator alone in 16 samples of surrounding mucosa. The procedure was similar to that described by Rijken et al. ${ }^{13}$ Results were determined from a standard dilution curve of the appropriate activator and expressed in $\mathrm{IU} / \mathrm{ml}$.

Zymography-Sodium dodecyl sulphate polyacrylamide gel electrophoresis of selected supernatants was performed according to the method of Laemmli using a $10 \%$ separating gel. ${ }^{14}$ Standards of urokinase and tissue plasminogen activator at appropriate dilutions were run as markers with test samples. Gels were subsequently washed in 2\% Triton X-100 and overlaid on to plasminogen enriched fibrin agarose plates and incubated at $37^{\circ} \mathrm{C} .{ }^{15}$ Gels were photographed before and after staining with Coomassie blue when clear lysis bands were visible.

Statistics-Results were expressed as medians and ranges and analysed by the Mann-Whitney U test.
Urokinase-Malignant tissue had significantly higher activities of urokinase detected by both assays as compared with the low values found in normal mucosa $(p<0.001)$. There were no differences between centre and edge of the tumours. Surrounding mucosal samples, examined only by bioimmunoassay, were not different from distant mucosa. Eight adenomatous polyps, however, had significantly higher immunological urokinase activities than normal mucosa $(\mathbf{p}<0.01)$ and three of six polyps assessed by bioimmunoassay showed values in the cancer range.

Zymograms of normal mucosal supernatants from 14 patients showed a dominant tissue plasminogen activator band; nevertheless, a high molecular weight urokinase band (figure) was always evident, and in four adenomatous polyps both bands were seen. Twelve carcinoma supernatants examined by this technique also showed both a tissue plasminogen activator and a high molecular weight urokinase band, often with the urokinase band appearing more rapidly. No bands corresponding to low molecular weight urokinase or to complexes of either urokinase or tissue plasminogen activator with their fast acting inhibitor were seen.

\section{Discussion}

These results show that the development of malignancy in the colorectal epithelium was almost invariably accompanied by increased production of urokinase. This enzyme was, however, present in very low concentrations in normal colorectal epithelium, as shown by bioimmunoassay and enzyme linked immunosorbent assay and confirmed by zymography. This finding is in contrast with a single previous zymographic study which failed to detect urokinase in normal colorectal mucosa, ${ }^{7}$ prompting claims that this enzyme is tumour specific. In adenomatous polyps the activities of urokinase and tissue plasminogen activator were also significantly different from those in normal mucosa and mirrored the changes seen in carcinomas. The findings in polyps accord with observations in experimental carcinogenesis, where aberrations in production of plasminogen activators often precede the morphological features of malignancy. ${ }^{16}$

It was not possible to define the cellular origin of plasminogen activators or to account for the possible variability in cellular composition among tissue samples. Probably, however, transformed epithelial cells are the source of plasminogen activators (particularly urokinase) within tumours, as other studies have shown the production of these enzymes by epithelial cells derived from both colorectal carcinomas ${ }^{1718}$ and adenomatous polyps ${ }^{18}$ 
in culture. Immunocytochemical studies have also shown urokinase to be associated with neoplastic epithelial cells in colonic cancer, ${ }^{819}$ and it has been postulated that urokinase may be released by tumour epithelial cells into the stroma, where it has also been detected. ${ }^{8}$ Though infiltrating white cells are a further potential source of protease activity in tumours, lymphocytes have been shown to produce negligible amounts of plasminogen activators unless themselves transformed-for example, by human $\mathrm{T}$ cell lymphotropic virus type $\mathrm{III}^{20}$ - when appreciable amounts of plasminogen activator, always including urokinase, were apparent. Moreover, the urokinase content of colonic mucosa from inflammatory bowel disease has been shown not to differ from normal, ${ }^{21}$ further supporting the view that the production of this enzyme is a particular feature of transformed cells. of vascularity and is in keeping with current concepts of the wider distribution and physiological role of tissue plasminogen activator. ${ }^{27}$ Previous discrepancies regarding the fibrinolytic activity of normal as compared with malignant colorectal tissue are explained by the fibrin dependence of plasminogen activation by tissue plasminogen activator and whether the methods used were fibrin dependent or independent. ${ }^{28}$ Thus the enhanced fibrin plate activity of normal mucosa in this investigation was consistent with the raised activities of tissue plasminogen activator found in this tissue and with previous fibrin plate studies. ${ }^{29}$

It has been postulated that the invasive edge of a tumour is associated with enhanced protease activity and that malignant cells may induce host tissues to release proteolytic enzymes. ${ }^{30}$ Tissue from the tumour edge and surrounding mucosa was therefore

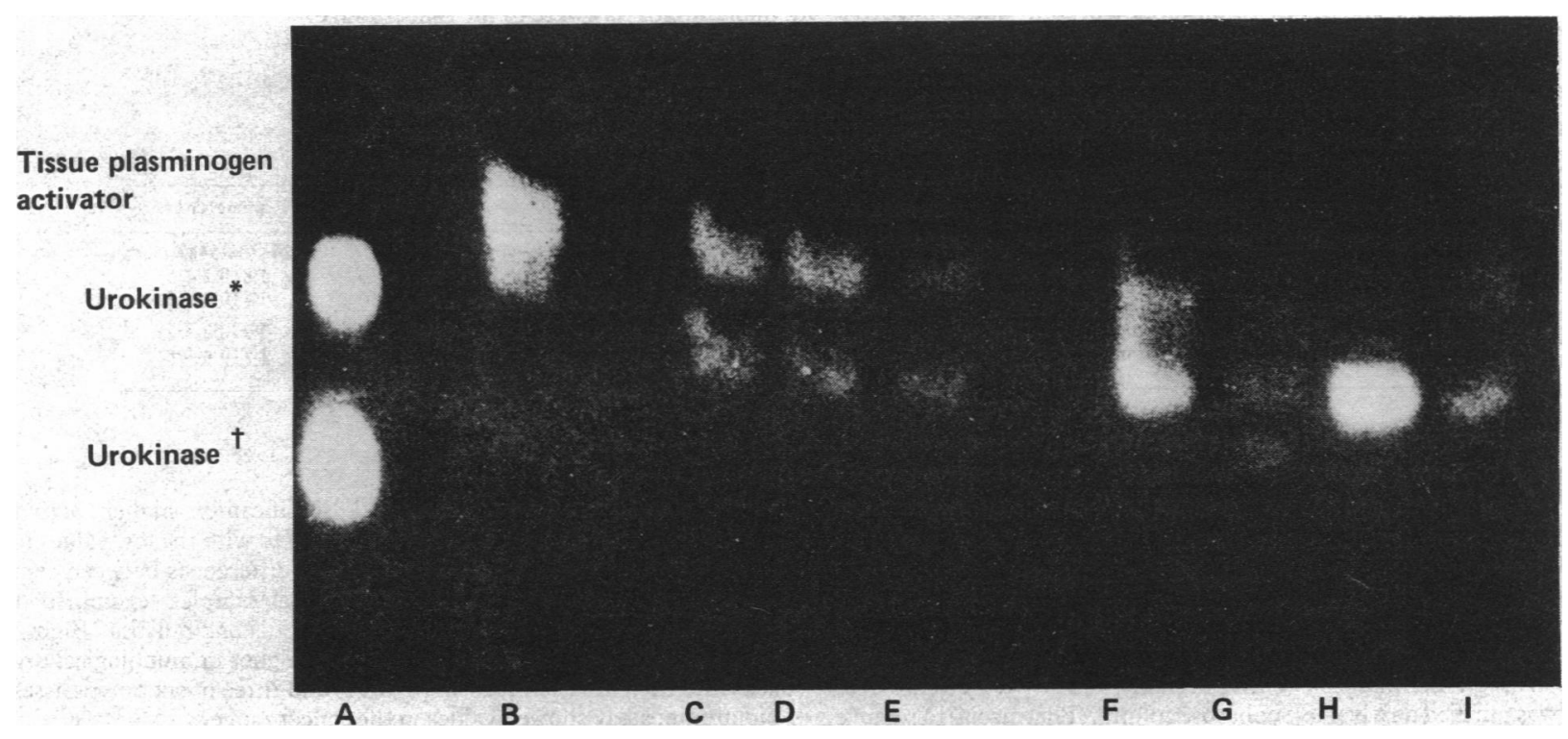

Zymogram of normal mucosa and neoplastic colorectal tissue. A=International standard of urokinase ( $\star 54$ kilodaltons, $† 31 \mathrm{kilodaltons)} 5 \mathrm{IU} / \mathrm{ml}$. $\mathrm{B}=$ International standard of tissue plasminogen activator $(68 \mathrm{kilodaltons}) 10 \mathrm{IU} / \mathrm{ml}$. C-E $=$ Normal mucosa. F-H $=\mathrm{Carcinomas}$. $\mathrm{I}=\mathrm{Villous}$ adenoma.

There was no relation between activity of plasminogen activator and tumour grade or Dukes's stage in this study, though the numbers were small. This may also relate to the comparatively wide ranges of activity found, which we considered were a consequence of biological variability, tumour heterogeneity, and methodology. In two of three patients with disseminated disease, however, urokinase activity (shown by bioimmunoassay) ranked first and third highest.

The generation of plasmin from plasminogen by urokinase, unlike tissue plasminogen activator, is not fibrin dependent and may therefore be regarded as less specific. ${ }^{22}$ Thus a tumour producing urokinase may have an enhanced capacity to generate plasmin, a broad spectrum proteolytic enzyme with trypsin-like activity. ${ }^{23}$ Plasmin has been shown to stimulate cell turnover in vitro $^{24}$ and is thought to play a crucial part in the destruction of basement membrane, ${ }^{923} 25$ a key event in the transition from benign polyp to carcinoma. Furthermore, the malignant behaviour in vitro of cells derived from colorectal carcinomas and adenomatous polyps when stimulated by tumour promoters correlated with their capacity to secrete urokinase. ${ }^{18}$ Moreover, antibodies to urokinase have been shown to inhibit experimental metastasis, ${ }^{26}$ further suggesting that this enzyme may have a functional role in human colorectal cancer.

Tissue plasminogen activator has not previously been assayed in normal colorectal mucosa. This study clearly showed that this tissue was rich in functional tissue plasminogen activator as compared with carcinomas and polyps. Probably this is not simply a reflection examined and, while there were no differences between tumour centre or edge, surrounding mucosa had less tissue plasminogen activator activity compared with distant mucosa. Possibly methodological problems related to the small size of the surrounding mucosal biopsy sample may have contributed to the tissue plasminogen activator findings. It has been suggested that colorectal and breast cancers produce the recently described fast acting inhibitor of tissue plasminogen activator, ${ }^{7}$ which has been associated with reduced fibrinolytic activity and thrombotic phenomena. ${ }^{31}$ Our study does not support this finding, immunological activities of tissue plasminogen activator not being higher than functional values and no bands corresponding to activator inhibitor complexes being detected by zymography.

Thus the sequential changes in urokinase and tissue plasminogen activator production that we found were in keeping with the concept of an adenoma-carcinoma sequence in colorectal neoplasia. While the progression of colorectal neoplasia is certain to be multifactorial, other proteolytic enzymes have recently been implicated in the invasive capacity of malignant tumours. ${ }^{32}$ The physiology of urokinase and the pattern of its production, supported by previous evidence implicating this enzyme in cancer, suggest that it may well play a part in the progression of both premalignant and malignant colorectal tumours.

JSKG and PBB acknowledge support from Smith Kline and French and from the special trustees of University College Hospital. 


\section{References}

1 Peterson HI, Kjartansson I, Korsan-Bengsten KB, Rudenstam CM, Zettergren L. Fibrinolysis in human malignant tumours. Acta Chir Scand 1973;139:219-23.

2 Liotta LA, Goldfarb RH, Brundage R, Siegal GP, Terranova V, Garbisa S. Effect of plasminogen activator (urokinase), plasmin, and thrombin on glycoprotein and collagenous components of basement membrane. Cancer Res 1981;41:4629-36.

3 Quigley JP. Proteolytic enzymes of normal and malignant cells. In: Hynes RO, ed. Surfaces of normal and malignant cells. Chichester: John Wiley and Sons, 1979:247-85.

4 Corsanti JG, Celik C, Camiolo SM, et al. Plasminogen activator content of human colon tumors and normal mucosae: separation of enzymes and partial purification. fNCI 1980;65:345-51.

5 Clifton EE, Grossi MD. Fibrinolytic activity of human tumors as measured by the fibrin plate method. Cancer 1955;8:1146-54

6 Malone JM, Wangensteen MD, Moore WS, Keown K. The fibrinolytic system. A key to tumor metastasis? Ann Surg 1979;190:342-9.

7 Tissot JD, Hauert J, Bachmann F. Characterisation of plasminogen activators from normal human breast and colon and from breast and colon carcinomas. Int $f$ Cancer 1984;34:295-302. 8 Kohga S, Harvey SR, Weaver RM, Markus G. Localization of plasminogen activators in human colon cancer by immunoperoxidase staining. Cancer Res 1985;45:1787-96.

9 Dano K, Andreassen PA, Grondahl-Hansen J, Kristensen P, Nielsen LS, Shriver L. Plasminogen activators, tissue degradation and cancer. Adv Cancer Res 1985;44:138-265.

10 de Cossart L, Marcusson RW. A simple quantitative assay of tissue plasminogen activator. $\mathcal{F} \mathrm{Clin}$ Pathol 1982;35:980-3.

11 Marsh NA. Fibrinolysis. Chichester: John Wiley and Sons, 19811:213-4.

2 Mahmoud M, Gaffney PJ. Bioimmunoassay (BIA) of tissue plasminogen activator (tPA) and its specific inhibitor (tPA Inh). Thromb Haemost 1985;53:356-9.

13 Rijken DC, Van Hinsbergh VWM, Sens EHC. Quantitation of tissue type plasminogen activator in human endothelial cell cultures by use of an enzyme immunoassay. Thromb Res 1984;33: $145-53$.

14 Laemmli UK. Cleavage of structural proteins during assembly of the head of bacteriophage T4 Nature 1970;227:680-5.

15 Granelli-Piperno A, Reich E. A study of protease and protease-inhibitor complexes in biological fluids. 7 Exp Med 1978;148:223-34.

16 Green LJ, Rumsby PS, Roscoe JP. An increase in plasminogen activator mRNA occurs at an early stage in ethylnitrosourea induced transformation of rat brain cells. Carcinogenesis 1986; 7 $477-80$.

17 Carretero F, Fabra A, Adan J, et al. Fibrinolytic activity of human invasive tumours and derived primary cultures. In: Davidson JF, ed. Progress in fibrinolysis. London: Churchill Livingstone, 1985:276-9.
18 Friedman $\mathrm{E}$, Urmacher $\mathrm{C}$, Winawer $\mathrm{S}$. A model for human colon carcinoma evolution based on the differential response of cultured preneoplastic, premalignant, and malignant cells to 12-O-tetradécanoyl-phorbol-13-acetate. Cancer Res 1984;44:1568-78.

19 Burtin P, Chavanel G, Andre J. The plasmin system in human colonic tumors: an immunofluorescence study. Int f Cancer 1985;35:307-14.

20 Hinuma S, Honda S, Tsukamoto K, Sugamara K, Hinuma Y. Production of plasminogen activators by human $\mathrm{T}$-cell leukaemia virus-transformed human $\mathrm{T}$ cell lines. $\mathrm{Br} \mathcal{f}$ Cancer 1985;51:753-9.

21 Verspaget HW, De Bruin PAF, Neterman IT, et al. Changes in plasminogen activator activity in inflammatory bowel disease (IBD). Gut 1986;27:A630.

22 Matsuo O, Rifken DC, Collen D. Comparison of the relative fibrinolytic and thrombolytic properties of tissue plasminogen activator and urokinase in vitro. Thromb Haemost 1981;45: $225-9$

23 Duffy MJ, O'Grady P. Plasminogen activator and cancer. Eur f Cancer Clin Oncol 1984;20: $577-82$

24 Whur P, Silcox JJ, Boston JA, Williams DC. Plasminogen activator transforms the morphology of quiescent 3 T 3 monolayers and initiates growth. Br f Cancer 1979;39:718-30.

25 O'Grady RL, Upfold LI, Stephens RW. Rat mammary carcinoma cells secrete active collagenase and activate latent enzyme in the stroma via plasminogen activator. Int $\mathcal{f}$ Cancer 1981;28: 509-15.

26 Ossowski L, Reich E. Antibodies to plasminogen activator inhibit human tumor metastasis. Cell 1983;33:616-9.

27 Granelli-Piperno A, Reich E. Plasminogen activators of the pituitary gland: enzyme characterisation and hormonal modulation. $\mathcal{F}$ Cell Biol 1983;97:1029-37.

28 Gelister JSK, Mahmoud M, Gaffney PJ, Boulos PB. Proteinase-like peptidase activities in malignant and non-malignant gastric tissue. Br $\mathcal{F}$ Surg 1986;73:84-5.

29 Szczepanski $M$, Lucer $C$, Zawadzki J, Tolloczko T. Procoagulant and fibrinolytic activities of gastric

30 Wooley DE. Collagenase immunolocalisation studies of human tumours. In: Liotta LA, Hart IR, eds. Tumour invasion and metastasis. The Hague: Martinus Nijhoff, 1982:391-404

31 Julian-Vague I, Moerman B, De Cock F, Ailland MF, Collen D. Plasma levels of a specific inhibitor of tissue type plasminogen activator (and urokinase) in normal and pathological condicions. Thromb Res 1984:33.523-30.

32 Durdey P, Cooper JC, Switala S, King RFGJ, Williams NS. The role of peptidases in cancer of the rectum and sigmoid colon. Brf Surg 1985;72:378-81.

Accepted 26 June 1986

\section{SHORT REPORTS}

\section{Clearance of psoriasis with low dose cyclosporin}

Previous studies have shown that $T$ helper lymphocytes play an integral part in the pathogenesis of psoriasis. ${ }^{1.3}$ Cyclosporin $\mathrm{A}$ is a selective immunosuppressive drug that specifically inhibits $T$ helper cell function by impairing the production and effects of interleukin-2. ${ }^{4} \mathrm{We}$ therefore studied the efficacy of cyclosporin A in the treatment of psoriasis, using low doses because of its dose related nephrotoxic effects.

\section{Patients, methods, and results}

We studied 10 patients with severe psoriasis that was unresponsive to conventional treatment (including methotrexate and psoralens and ultraviolet $\mathbf{A}$ ) (table). Informed consent was gained from each patient before entry to the study. Cyclosporin A was taken once daily in the evening for 12 weeks. In eight patients the initial daily dose was $1.66 \mu \mathrm{mol} / \mathrm{kg}(2 \mathrm{mg} / \mathrm{kg}$ ); the other two, who had very severe active disease, were given $2.49 \mu \mathrm{mol} / \mathrm{kg}(3 \mathrm{mg} / \mathrm{kg})$. The dose was increased by $0.83 \mu \mathrm{mol} / \mathrm{kg}(1 \mathrm{mg} / \mathrm{kg})$ if there was no improvement after two weeks' treatment; the agreed maximum dose was $3.32 \mu \mathrm{mol} / \mathrm{kg} / \mathrm{day}(4 \mathrm{mg} / \mathrm{kg} / \mathrm{day})$ Patients were assessed before treatment and at three days and one, two, three, four, six, eight, and 12 weeks. Before treatment and at each subsequent visit the following investigations were performed: blood pressure, urine analysis, urea and electrolyte concentrations, serum creatinine concentration, liver function, and full blood count. Blood cyclosporin concentrations were measured by radioimmunoassay as whole blood trough concentration about 12 hours after the last dose. The area of skin affected was determined at each visit and severity rated on a scale of $0-10$

Psoriasis cleared completely in five of the 10 patients and there was an appreciable improvement in the other five. Of the five in whom psoriasis cleared completely, clearance was achieved by six weeks in case 1 and by eight weeks in cases $2,3,4$, and 5 (table). The therapeutic dose of cyclosporin A seemed to be $2.49 \mu \mathrm{mol} / \mathrm{kg} / \mathrm{day}(3 \mathrm{mg} / \mathrm{kg} / \mathrm{day}) ;$ increasing the dose to $3.32 \mu \mathrm{mol} / \mathrm{kg} / \mathrm{day}(4 \mathrm{mg} /$ $\mathrm{kg} / \mathrm{day}$ ) did not induce clearance in those in whom the disease had not cleared at the lower dose. There was no correlation between clinical response and whole blood cyclosporin concentrations, and in all but one patient concentrations were less than $0.62 \mu \mathrm{mol} / \mathrm{l}(750 \mathrm{ng} / \mathrm{ml})$ on all occasions. Two patients experienced an increase in blood pressure, and in four serum creatinine concentration increased by more than $10 \%$ during the study, though the values were still within the normal range. Three of the six women developed hypertrichosis, consisting of fine lanugo hairs on the face and coarse terminal hairs on the legs. All three said that they were prepared to tolerate this side effect if their psoriasis cleared

Clinical data on patients with psoriasis participating in study

\begin{tabular}{|c|c|c|c|c|c|c|c|c|c|c|}
\hline \multirow[b]{2}{*}{ Case No } & \multirow[b]{2}{*}{ Age/sex } & \multirow{2}{*}{$\begin{array}{l}\text { Previous } \\
\text { systemic } \\
\text { treatment }\end{array}$} & \multicolumn{2}{|c|}{$\begin{array}{l}\text { Body area } \\
\text { affected }^{\star}\end{array}$} & \multicolumn{2}{|c|}{$\begin{array}{l}\text { Blood pressure } \\
(\mathrm{mm} \mathrm{Hg})\end{array}$} & \multicolumn{2}{|c|}{$\begin{array}{l}\text { Creatinine concentration } \\
(\mu \mathrm{mol} / \mathrm{l})\end{array}$} & \multirow{2}{*}{$\begin{array}{c}\text { Cyclosporin A } \\
\text { dose } \\
(\mu \mathrm{mol} / \mathrm{kg} / \text { day })\end{array}$} & \multirow{2}{*}{$\begin{array}{l}\text { Mean (range) } \\
\text { cyclosporin A blood } \\
\text { concentrations } \\
(\mu \mathrm{mol} / \mathrm{l})\end{array}$} \\
\hline & & & $\begin{array}{c}\text { Start } \\
\text { of study }\end{array}$ & $\begin{array}{l}\text { End } \\
\text { of study }\end{array}$ & $\begin{array}{c}\text { Start } \\
\text { of study }\end{array}$ & $\begin{array}{l}\text { End } \\
\text { of study }\end{array}$ & $\begin{array}{c}\text { Start } \\
\text { of study }\end{array}$ & $\begin{array}{l}\text { End } \\
\text { of study }\end{array}$ & & \\
\hline 1 & $38 / \mathrm{F}$ & Methotrexate & 5 & 0 & $100 / 80$ & $120 / 85$ & 68 & 85 & $1 \cdot 66-2 \cdot 49$ & $0.23(0.11-0.32)$ \\
\hline 2 & $32 / \mathrm{F}$ & PUVA & 5 & 0 & $105 / 80$ & $125 / 80$ & 87 & 89 & $1 \cdot 66-2 \cdot 49$ & $0 \cdot 17(0 \cdot 11-0 \cdot 25)$ \\
\hline 3 & $51 / \mathrm{F}$ & PUVA & 5 & 0 & $140 / 80$ & $120 / 75$ & 85 & 75 & $2 \cdot 49$ & $0.31(0.25-0.34)$ \\
\hline 4 & $40 / M$ & PUVA & 2 & 0 & $125 / 85$ & $130 / 85$ & 91 & 112 & $1 \cdot 66-2 \cdot 49$ & $0.30(0 \cdot 16-0.39)$ \\
\hline 5 & $55 / \mathrm{F}$ & PUVA, Methotrexate & 3 & 0 & $150 / 90$ & $130 / 90$ & 80 & 73 & $1 \cdot 66-2 \cdot 49$ & $0.51(0.31-0.60)$ \\
\hline 6 & $33 / \mathrm{M}$ & PUVA, Methotrexate & 7 & 1 & $135 / 90$ & $140 / 80$ & 94 & 76 & $1 \cdot 66-3 \cdot 32$ & $0.47(0.26-0.61)$ \\
\hline 7 & $64 / \mathrm{F}$ & Methotrexate, PUVA & 5 & 1 & $125 / 85$ & $130 / 80$ & 65 & 65 & $1 \cdot 66-3 \cdot 32$ & $0.26(0 \cdot 16-0.30)$ \\
\hline 8 & $42 / \mathrm{F}$ & PUVA & 2 & 1 & $140 / 90$ & $160 / 105$ & 85 & 98 & $1 \cdot 66-3 \cdot 32$ & $0.34(0.16-0.59)$ \\
\hline 9 & $62 / M$ & PUVA, Methotrexate & 5 & 2 & $120 / 85$ & $140 / 100$ & 84 & 94 & $2 \cdot 49-3 \cdot 32$ & $0.63(0.54-0.88)$ \\
\hline 10 & $38 / \mathrm{M}$ & Methotrexate, Razoxane & 3 & 2 & $140 / 95$ & $140 / 90$ & 94 & 95 & $1 \cdot 66-3 \cdot 32$ & $0.28(0.18-0.34)$ \\
\hline
\end{tabular}

${ }^{\star} 0=<1 \%, 1=1-10 \%, 2=11-20 \%, 3=21-30 \%, 4=31-40 \%, 5=41-50 \%, 6=51-60 \%, 7=61-70 \%, 8=71-80 \%, 9=81-90 \%, 10=91-100 \%$. PUVA=Psoralens and ultraviolet A treatment.

Conversion: SI to traditional units-Creatinine: $1 \mu \mathrm{mol} / 1 \approx 0.01 \mathrm{mg} / 100 \mathrm{ml}$. Cyclosporin A: $1 \mu \mathrm{mol} \approx 1 \cdot 2 \mathrm{mg}$. 